\title{
Fourth-Year Indonesian Medical Students' Time Management In Problem-Based Learning
}

\author{
Indah Puspasari Kiay Demak ${ }^{\mathrm{a}, \mathrm{b}, 1,{ }^{*},}$, Mauren Chesaria Wenno ${ }^{\mathrm{c}, 1}$ \\ ${ }^{\text {a }}$ Medical Education Unit, Faculty of Medicine, Tadulako University \\ ${ }^{\mathrm{b}}$ Public Health and Community Medicine Department, Faculty of Medicine, Tadulako University \\ ${ }^{\mathrm{c}}$ Department, Faculty of Medicine, Tadulako University \\ ${ }^{1}$ sashkata@yahoo.com \\ * corresponding author
}

ARTICLE INFO

Article history

Received

Revised

Accepted

Keywords

Time Management

Medical Student

Problem-based learning

\section{ABSTRACT}

Introduction: problem-based learning involves the student in its learning process. The students are expected to do independent learning in every aspect of learning events, which is very effective to students depend on how they can manage their own schedules and their own activities. Method: This was a qualitative study. The subjects were twenty-six medical students with focus group discussion method; it has one key informant and 26 common informants. Data analysis used matrix technique where the information was processed in the table, and they were: number, informant's name, emik, ethic, conclusion and displayed in descriptive narration Results and Discussion: Students with good time management had characteristics of play an active role in answering and asking questions, have a lot of information about the case in the scenario, understand the explanation given by friends, and achieve the learning objectives given in the tutorial discussion. While students with poor time management were still looking for the materials during the tutorial discussion, confused by the explanation given by friends during the tutorial, passive during the tutorial, and give opinions during the discussion, but no relevant reference Conclusion: The strategy used by students is reading tutorial material and discussing with friends before the session. The importance of time management in implementing problem-based learning is that students can comprehensively study the given cases and encourage students to actively identify and solve problems in discussions

This is an open-access article under the CC-BY-SA license.

\section{Introduction}

Studying in college is not the same as the learning process at the high school level. The difference lies in the models, strategies, and learning techniques. Besides, the scope of the topics received in lectures is more comprehensive than at the high school level. For this reason, as a student, skills are needed in carrying out activities as a student and managing time to study (Liveris \& Cavanagh, 2012).

Management is a skill in processing, planning, organizing an activity to achieve goals effectively and efficiently. Effective means that the goals can be achieved according to the plan, while efficient means that the tasks are carried out correctly, organized, and according to schedule. Time management is the way people use time as optimally as possible through planning, scheduling, controlling time, and making priorities according to their interests. The desire to be organized can be seen from behavior such as organizing the workplace and not procrastinating the work completed (Mulyani, 2013). 
Students' time management skills include activities such as planning, prioritizing work, preparing for exams, and following lecture schedules. Students achieve good academic a by balancing time management and effective study techniques. Good time management behaviors such as setting goals and prioritizing activities can minimize stress, work more effectively and be academically successful (Adams \& Blair, 2019).

Three factors influence time management, namely self-regulation, motivation, and goal setting. While some of the obstacles that are often encountered when managing time including procrastination, violating deadlines, and mood changes. Time management strategies, namely getting used to preparing lists, planning certain activities to be carried out at certain times, finding optimal working time, prioritizing tasks based on their level of importance, organizing, delegating, and being able to distinguish between "immediate" and "important" (Ahmad Uzir et al., 2019).

In the last few decades, universities have introduced learning programs where students play an active role, develop themselves, and learn in a structured and collaborative way. Problem-based learning is one way of learning that is generally used for constructive social concept learning. The characteristic of problem-based learning is that students learn in small groups and work together to solve problems and work with structured tasks (Zwaal \& Otting, 2016). The principle of collaborative learning supports the way PBL works, and collaboration in groups is one of the prerequisites for the benefits of PBL as a realizable learning approach (Murray-harvey et al., 2013). The advantage is that students have an independent learning process, have the motivation to learn, and have knowledge from various disciplines (Mansur et al., 2012).

Medical and health education is a dynamic education with a learning model that emphasizes the active role of students in the learning process rather than passively understanding and applying knowledge. The Tadulako University Medical Study Program has implemented an education system with a Competency-Based Curriculum since 2008. The aim of this study is to explore how fourthyear medical students manage their time for study in the setting of problem-based learning.

\section{Method}

This research was a descriptive study with a qualitative approach. The subjects were 26 fourthyear Tadulako University medical students selected by purposive sampling technique. In Indonesia, medical education is divided into two stages: the preclinical and clinical stages. Fourth-year students are final-year students in the preclinical phase. The researcher interviewed the subject in a focus group discussion, which was divided into two groups. Interviews were conducted in 2017. The data were analyzed through thematic analysis

\section{Results and Discussion}

\subsection{Results}

The medical study program at Tadulako University has used a problem-based curriculum since it was first established in 2008. The curriculum in the preclinical phase consists of 8 semesters that are programmed in 4 years, consisting of 22 integrated system blocks. Each block is implemented for seven weeks. Every week there are two tutorial discussion meetings. The tutorial discussion discusses case scenarios according to blocks.

\section{Students' perspectives about problem-based learning}

Problem-based learning (PBL) is a process of learning using scenarios that must be solved together:

"It means that PBL learns from a problem, a scenario is given in which there is a problem, which we have to discuss." (G1M2.7-10)

"Problem-based learning means that we learn from real cases or problems and we are asked to think critically in assessing the problem, and we continue to find out or solve the problem, and that's all." (G1M9.58-62) 
PBL is student-centered learning where students are required to play an active role in the discussion:

"PBL students are the center who will be given a case and then find a solution to the problem by looking for appropriate references." (G3M7.159-163)

\section{$\underline{\text { Study time management model }}$}

Most students said that time management is a way for students to divide and manage their time with student activities for work planned for both the short and long term so that it can be carried out properly and run optimally.

"that is, how do we manage time, according to what we expect" (G2M3.693-695)

"how do we manage time, set the agenda, so that everything that is planned and arranged can all be carried out properly." (G2M1,679-682)

Time management is the way a person divides and runs time according to a priority scale that is prioritized to do:

"If it's time management, I think how do we manage our time, what do we do first." (G3M7.1593-1596)

"Management at that time was where we prioritized our priority programs, what was important, what we prioritized immediately." (G3M4.11611-1614)

However, students still experience problems in managing time:

"it has not been managed properly, because it is still not possible to distinguish which things should take precedence or priority" (G1M5.134-137)

Students have not been able to do time management properly due to too high a sense of laziness and many sudden things that suddenly make students not carry out the things that have been planned, and some students do things according to the students' mood.

"I'm a person who can't do it yet. Then, if it's like an agenda, I usually make notes like what kind of tasks I want to do and what tasks I want to complete. However, usually, I can manage my time well if, for example, there are a lot of things that don't pile up on the agenda, because it's so there are so many, we're like we'll take a break, so like it or not, it's a lot of work." (G2M1.874-884)

Those who have not been able to manage this time depend on their intentions, and mood, while those who are already good enough to do this time management have part of the planned schedule going well.

"I haven't, because it is influenced by many factors, first maybe because there is a sudden schedule, usually because I am lazy..." (G3M5.1661-1667)

Students prefer to study when it is approaching exam time.

"If I don't have a benchmark, it also depends on how the needs are if there is an exam or what, it's only 4 hours of study that night" (G1M4.183-186)

"It's also uncertain, so usually when there is an exam, it's about 2 hours at most, on the day it's at most 30 minutes from 8 to 9 o'clock." (G3M6 1724-1727)

Students like to procrastinate because they have many other activities besides learning. 
"The difficulty is with the many activities we have on campus or other additional activities, so if we prepare the materials for the preparation the next day there are problems with that, personally from me too where the feeling of laziness is still too high where we are still procrastinating" (G1M3.237-238)

Time management difficulties in the implementation of problem-based learning.

"When it's busy, we just got the case first; then we haven't got the expert lecture, right, then we print the script schedule. Usually, we only get the scenario on the D day, then it's difficult to get a reliable reference." (G3M8.1836-1841)

\section{$\underline{\text { Strategies for good time management }}$}

The strategy in learning is to study the lecture slides given before the tutorial, the night before the tutor, or the day before the tutorial takes place.

"When the H min one day, we can handle it either at night or right in front of going to the tutorial, right before entering the lecturer, you can wait while looking around first." (GIM1 355-359)

Another strategy is to collect information from friends who have studied, conduct discussions before entering the tutorial, and look for words or materials that are not understood the night before the next day's tutorial, either on the internet or in books.

"I looked at the terms, but automatically the terminology that I didn't understand, I looked for what it meant, then I looked at Tong Mi again, the usual scenario is that there are typical signs, so I thought about what the diagnosis was, so if it's obvious, I'll look for the disease. Everyone, so I'm looking for something like a kind of draft that discusses the disease. I read it... just read it but sometimes if there's something important, I write it down... and the next day, before the tutorial, I look for my friends who are good at taking notes material before

the tutorial, then I ask for the notes, I will copy them, then we will have a small discussion" (G2M6 1065-1082)

"So, at least if you want the tutorial, I only collect sources of information from friends who are learning so much, so I asked you, what do you think about the scenario while waiting for my tutor to read the scenario, only if it's a special strategy" (G2M2.1026 -1032)

Reasons for the Importance of Learning Time Management in Problem-based learning

If time management is good, it means that the student is ready for discussion to be more active in the discussion and follow the course of the discussion well.

"Is it possible if there is preparation, we can perform better in the discussion, if there is no preparation, what do you want to say, while what you want to say is friends inside later" (G2M2.1485-1492)

"There is a difference. For a concrete example, if the time management is good, he will talk a lot. If there is no division of study time, he will not talk much during the tutorial or do not know what is being discussed." (G3M2. 2061-2067) 


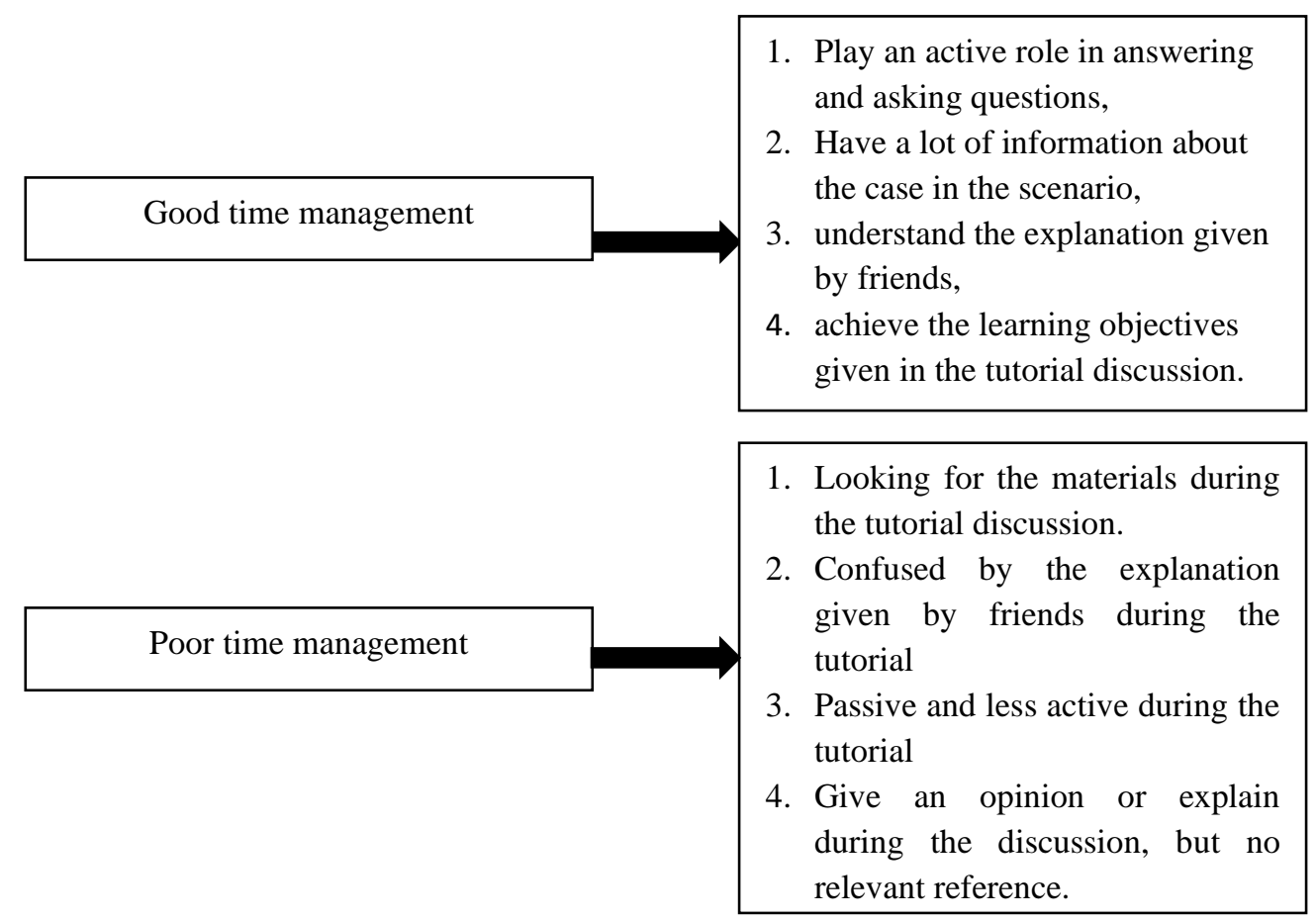

Fig 1. Types Of Time Management Of Fourth-Year Medical Students

\subsection{Discussion}

PBL is one of the innovative methods in learning, one of its effectiveness is facilitating students to solve problems and have the ability to learn independently (Yew \& Goh, 2016). Furthermore, time management is a principle, practice, skill, equipment, and system that work together to help someone get more value from your time by improving our quality of life. The object of time management is to increase and optimize the use of available free time. Time management is not about doing many things in one day. It is about doing the things that matter most. Time management is the ability to decide what is most important in life at work, at home, and even in personal life (Ojo \& Olaniyan, 2008).

Time management strategy is determined by time management principles as follows (1) Knowing the purpose of life by prioritizing based on goals, (2) Avoiding doing urgent things by identifying essential things, (3) Knowing how to use technology so that can save time, (4) Can use time efficiently by starting meetings on time, stay on the subject and not use the time for things that are not important, and (5) Able to stay productive while on the go (MacCann et al., 2012).

Many students have the habit of absorbing all the information before the exam, staying up all night to read the material. According to research, students should bring it every day and have a particular time to study. When they study by only reading the material for one night, the stored material can only last for a few hours and will not be remembered for a long time. especially medical students must remember the information at all times because they will use it in their daily lives to help and treat society for that medical students must have the habit of studying and reading all the time. (Gordon \& Borkan, 2014).

In terms of time management in general, fourth-year students of the medical education study program still have good time management in general. have not been able to set the priority scale 
(G1M5 134-137). and some students also have not been able to manage time well because they are still doing things according to their mood. (G3M6 1672-1675) and some can do good time management because they can share organizational activities with academics (G2M8. 777-782) and have carried out what was planned about $60 \%$. (G2M3, 841-945) The principle of time management relates to the ability and attitude of individuals in determining the priority scale in making the best use of the time they have. Deadlines and targets missed from the time limit are due to the assumption that there is still a lot of free time available and time wasted is normal. Students' time management strategy in implementing PBL is carried out by conducting discussions before implementing PBL (G2M2) and looking for materials before the PBL Process takes place. Learning together will be more effective in learning time, and can learn about all material topics and to make a good study discussion one must choose the right person and organize the learning process.

The curriculum for learning from problems has a lot of learning content, so it has a lot of learning time needed. Besides, students have a busy schedule of activities, and demands for high academic standards make students have to manage their study time as well as possible. Overcome these obstacles, and a time management strategy is needed. Time management can be done by formulating problems about what and how a task will be completed, providing time to ensure that the plans that have been made are following the goals to be achieved (Chase et al., 2013).

The reason for the importance of time management in the implementation of tutorials is to make students have a lot of material being studied so that they are active in the discussion process (G1M4 456-467) to achieve learning objectives (G2M8 1416-1419), make students understand the discussion; it becomes a habit to be able to organize activities well in future life. According to research, students should bring it every day and have a particular time to study. When they study by only reading one night, the stored material can only last for a few hours and will not be remembered for a long time. Remember this information at all times because they will use it in their daily lives to help and heal the community for that medical students must have the habit of studying and reading all the time (Gordon \& Borkan, 2014).

\section{Conclusion}

Most students already have good time management, although some are still unable to determine priorities, which leads to procrastination. The strategy used by students is reading tutorial material and discussing with friends. The importance of time management in implementing problem-based learning is that students can comprehensively study the given cases and encourage students to actively identify and solve problems in discussions.

\section{Acknowledgment}

Thank you to all those who have helped in this research.

\section{References}

Adams, R. V., \& Blair, E. (2019). Impact of Time Management Behaviors on Undergraduate $\begin{array}{lllll}\text { Engineering Students' } & \text { Performance. }\end{array}$ https://doi.org/10.1177/2158244018824506

Ahmad Uzir, N., Gašević, D., Matcha, W., Jovanović, J., Pardo, A., Lim, L. A., \& Gentili, S. (2019). Discovering Time Management Strategies in Learning Processes Using Process Mining Techniques. Lecture Notes in Computer Science (Including Subseries Lecture Notes in Artificial Intelligence and Lecture Notes in Bioinformatics), 11722 LNCS(September), 555-569. https://doi.org/10.1007/978-3-030-29736-7_41

Chase, J. A. D., Topp, R., Smith, C. E., Cohen, M. Z., Fahrenwald, N., Zerwic, J. J., Benefield, L. E., Anderson, C. M., \& Conn, V. S. (2013). Time Management Strategies for Research Productivity. Western Journal of Nursing Research, 35(2), 155-176. https://doi.org/10.1177/0193945912451163 
Gordon, C. E., \& Borkan, S. C. (2014). Recapturing time: A practical approach to time management for physicians. Postgraduate Medical Journal, 90(1063), 267-272. https://doi.org/10.1136/postgradmedj-2013-132012

Liveris, C., \& Cavanagh, R. (2012). A Phenomenological Analysis of the Self-Regulatory Behaviours of a Group of Young Adults in a Vocational Education and Training Business Program. Australian Association for Research in Education, 1-13. https://espace.curtin.edu.au/handle/20.500.11937/9695\%0Ahttps://search.proquest.com/docvi ew/1361848701?accountid=14511\%0Ahttps://ucl-newprimo.hosted.exlibrisgroup.com/openurl/UCL/UCL_VU2?url_ver=Z39.882004\&rft_val_fmt=info:ofi/fmt:kev:mtx:journal\&genre=

MacCann, C., Fogarty, G. J., \& Roberts, R. D. (2012). Strategies for success in education: Time management is more important for part-time than full-time community college students. Learning and Individual Differences, 22(5), 618-623. https://doi.org/10.1016/j.lindif.2011.09.015

Mansur, D. I., Kayastha, S. R., Makaju, R., \& Dongol, M. (2012). Problem-based learning in medical education. Kathmandu University Medical Journal, 10(40), 78-82. https://doi.org/10.3126/kumj.v10i4.11002

Mulyani, M. D. (2013). Hubungan Antara Manajemen Waktu Dengan Self Regulated Learning Pada Mahasiswa. Educational Psychology Journal, 2(1), 43-48.

Murray-harvey, R., Pourshafie, T., \& Reyes, W. S. (2013). What teacher education students learn about collaboration from problem-based learning. Journal of Problem Based Learning in Higher Education, 1(1), 114-134. https://doi.org/10.5278/ojs.jpblhe.v1i1.278

Ojo, L. B., \& Olaniyan, D. A. (2008). Effective time management in organization panacea or placebo. In European Journal of Scientific Research (Vol. 24, Issue 1, pp. 127-133).

Yew, E. H. J., \& Goh, K. (2016). Problem-Based Learning: An Overview of its Process and Impact on Learning. Health Professions Education, 2(2), 75-79. https://doi.org/10.1016/j.hpe.2016.01.004

Zwaal, W., \& Otting, H. (2016). Performance of the Seven-step Procedure in Problem-based Hospitality Management Education. 4(1), 1-15. 